\title{
PSA Level 0.1 to 50
}

National Cancer Institute

\section{Source}

National Cancer Institute. PSA Level0.1 to 50. NCI Thesaurus. Code C138321.

A blood concentration of prostate specific antigen between 0.1 and $50 \mathrm{ng} / \mathrm{mL}$. 